Short Communication

\title{
INVESTIGATION OF CYTOSTATIC ACTIVITY OF THE METHENAMINE SILVER IN VITRO AND IN VIVO
}

\author{
EVGENII PLOTNIKOV*1, VLADIMIR PLOTNIKOV² \\ 1Tomsk Polytechnic University, Lenin av. 30, Tomsk, Russia, ${ }^{2}$ Polytech Ltd, Asinovskaya Str. 7a, Tomsk, Russia \\ Email: plotnikov.e@mail.ru
}

Received: 14 Sep 2017 Revised and Accepted: 02 Nov 2017

\begin{abstract}
Objective: Developing of novel pharmaceutical agents is an actual topic for chemotherapy. Heavy metals possess significant cytotoxic properties and some of them are widely introduced in medical practice, e. g. cisplatin.

Methods: Silver salt of methenamine was suggested as prospective substance and tested was tested on black-motley cattle with bovine leukemia to reveal influence on haematological parameters. The preparation was applied in form of $0.5 \%$ solution in different doses and was administered as a single intravenous injection. Blood parameters were determined by triple haematological monitoring. Investigation of cytostatic activity was conducted on the leukemic cells of HUT-102 line in vitro in the concentration range of $0.03-3.0 \mathrm{mg} / \mathrm{ml}$.
\end{abstract}

Results: The results showed normalization of blood parameters in a dose-dependent manner after intravenous injection of methenamine silver salt. It was revealed a pronounced inhibitory effect of the silver-based drug on the leukemic cells both in vitro and in vivo. Control blood test one month after experimental therapy confirmed the stability of the achieved results.

Conclusion: The tested drug showed a moderate cytostatic effect. Methenamine silver nitrate can be considered as prospective pharmacological agent. Bovine leukaemia was shown as a convenient model for the development of new treatment of blood diseases. Continuation of the work is of interest for both veterinary and medical pharmacotherapy.

Keywords: Methenamine silver nitrate, HUT 102 cells, Lymphocytes, Leucosis, Cytostatic activity, Bovine leukemia, Silver hexamethylenetetramine

(C) 2017 The Authors. Published by Innovare Academic Sciences Pvt Ltd. This is an open-access article under the CC BY license (http://creativecommons.org/licenses/by/4.0/) DOI: http://dx.doi.org/10.22159/ijpps.2017v9i12.22575

Designing of novel cytostatic agents for leucosis treatment is a challenging task for modern pharmacology and medicine. Especially acute problem is a resistant form of decease [1-2]. A lot of modern approaches are used now for development delivery systems and screening of novel agents, e. g. virtual ligand screening [3-4]. Due to drug-resistivity, recently interest revived in the metal preparations of a new generation with cytostatic, antiviral and antibacterial activities [5-8]. Malignant and infectious diseases is a huge problem in veterinary practice as well, e. g. bovine leucosis causing enormous economic losses, and required new eradication approaches [9-10]. Currently, there are well-developed methods of laboratory diagnosis of bovine leukemia [11], but methods of treatment are not developed at all. Specific prophylaxis is only developed, but not introduced [12]. Bovine leukemia virus (BLV) is a retrovirus closely related to the human T-lymphotropic virus type $1 \mathrm{HTLV}-\mathrm{I}$. Bovine leukemia virus (BLV) is a valuable model system for investigation of human lymphotropic viruses [13]. Here we considered viral bovine leukemia as a very convenient model for testing of promising antiviral and cytostatic agents for the medical practice, where leukemia is still a major problem [14]. The aim of this work is to study the cytostatic activity of stabilized solution of methenamine silver nitrate under in vitro and in vivo conditions. Previously, it was shown a wide range of anti-infective activity of methenamine silver nitrate [15].

Investigation of antiblastic activity of methenamine silver nitrate was carried out on cattle with hematologically and serologically (radial immune-diffusion test) confirmed the diagnosis of bovine leukemia. All cows were black-motley breed, age 2-6 y, the weight of $450-670 \mathrm{~kg}$, the standard diet. Group of healthy cattle served as a control group (20 heads). All cows with bovine leucosis were randomly distributed in 2 experimental groups (15 animals each), depending on the dose of administration. The test preparation (methenamine silver nitrate) in $0.5 \%$ stabilized aqueous solution injected intravenously into the jugular vein at the dosage range of $0.3 \mathrm{mg} / \mathrm{kg}$ (first experimental group) and $0.9 \mathrm{mg} / \mathrm{kg}$ (second experimental group). The rates of the experimental dosages were chosen based on preliminary data to determine the acute and chronic toxicity in small laboratory animals; i.e. the value of the experimental doses about $1 \% \mathrm{LD}_{50}$. Blood parameters were determined by triple haematological monitoring (immediately before injection, during the week after and 1 mo after injection). Investigation of the drug cytostatic activity conducted on leukemic cells lines HUT-102 in the concentration range of $0.03-3.0 \mathrm{mg} / \mathrm{ml}$. Cells were cultured in RPMI-1640 medium with 15\% fetal calf serum according to standard procedures. After $24 \mathrm{~h}$ incubation, the percentage of viable cells was determined by flow cytometer. All results here are presented as mean \pm standard error of mean (SEM). Different groups of data were compared by Mann-Whitney U-test.

Results of in vitro testing of the drug at varying concentrations (table 1) showed a pronounce inhibitory effect on the leukemic cells with dose-dependent cytopathic effect.

Table 1: In vitro influence of methenamine silver nitrate on HUT 102 leukemic cells line, $n=3$ (mean \pm SEM)

\begin{tabular}{llll}
\hline & The percentage of viable cells of HUT-102 line, (\%) & \\
\hline $0.03 \mathrm{mg} / \mathrm{ml}$ & $0.3 \mathrm{mg} / \mathrm{ml}$ & $3 \mathrm{mg} / \mathrm{ml}$ & Control \\
$43 \pm 6$ & 0 & 0 & $92 \pm 3$ \\
\hline
\end{tabular}

Single intravenous administration of the experimental dose of 0.3 $\mathrm{mg} / \mathrm{kg}$, resulted in a slight decrease in the number of white blood cells to $14.4 \pm 1.1$ ths $/ \mu \mathrm{l}(13.7 \%$ recession $)$ and the absolute number of lymphocytes to $11.4 \pm 0.7$ ths $/ \mu$ l (13.6\% recession). Injection of single high dose $(0.9 \mathrm{mg} / \mathrm{kg})$ of the drug accompanied by more pronounced changes in the hematologic parameters, as shown in fig. 1. 


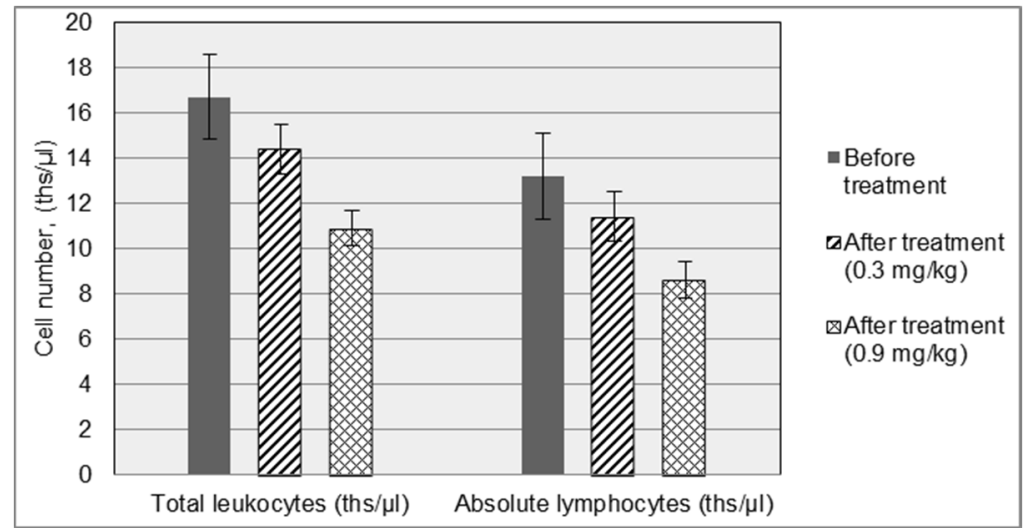

Fig. 1: In vivo influence of stabilized solution of methenamine silver nitrate on the white blood cells of cattle with leukemia, $\mathrm{n}=15$ (bars represent the standard errors of the mean)

The drug contributes to the normalization blood parameters, reducing the number of white blood cells to $10.9 \pm 0.8 \mathrm{ths} / \mu \mathrm{l}$ and the absolute lymphocyte count to $8.6 \pm 0.5$ ths $/ \mu \mathrm{l}$ as well as the disappearance of leukemic cells. However, these parameters were different from healthy control group, where the total number of white blood cells was $7.7 \pm 0.6$ ths $/ \mu$, the absolute number of lymphocytes was $5.4 \pm 0.3$ ths/ $\mu$ l. Additional hematologic monitoring one month after treatment confirmed the stability of the achieved results of experimental therapy.

Thus, tested silver-based drug revealed the moderate cytostatic effects with a tendency to normalization of the haematological parameters in experimental animals. It is important that bovine leukemia can be considered as a promising model for pharmacotherapy of blood malignant diseases.

\section{AUTHOR CONTRIBUTION}

All authors took part in experiments. Dr. Evgenii Plotnikov made a work concept, provide a chemical synthesis of preparation and wrote the manuscript. Dr. Vladimir Plotnikov drafted the manuscript and provide statistical analyses.

\section{CONFLICT OF INTERESTS}

\section{Declared none}

\section{REFERENCES}

1. Lan $\mathrm{X}$, Zhao $\mathrm{C}$, Chen $\mathrm{X}$, Zhang $\mathrm{P}$, Zang $\mathrm{D}, \mathrm{Wu}$ J, et al. Platinum pyrithione induces apoptosis in chronic myeloid leukemia cells resistant to imatinib via DUB inhibition-dependent caspase activation and Bcr-Abl downregulation. Cell Death Disease 2017;8:2913.

2. Meier Stephenson V, Riemer J, Narendran A. The HIV protease inhibitor, nelfinavir, as a novel therapeutic approach for the treatment of refractory pediatric leukemia. Onco Target Ther 2017;10:2581-93.

3. Kanagaraj B, Prakash A, Wadhwa G. An insight to virtual ligand screening methods for structure-based drug design and methods to predict protein structure and function in lung cancer: approaches and progress. J Crit Rev 2014;1:10-24.
4. Bonde S, Nair S. Advances in liposomal drug delivery system: fascinating types and potential applications. Int J Appl Pharm 2017;9:1-7.

5. Plotnikov E, Silnikov V, Gapeyev A, Plotnikov V. Investigation of DNA-damage and chromosomal aberrations in blood cells under the influence of new silver-based antiviral complex. Adv Pharm Bull 2016;6:71-4.

6. Silnikov V, Plotnikov E, Plotnikov V. Pharmacokinetic studies of new silver-based complex. Int J Pharm Pharm Sci 2015;7:41-3.

7. Mangaiyarkkarasi P, Arulantony S. DNA cleavage, cytotoxic activities, and antimicrobial studies of some novel schiff base transition metal complexes derived from 4-aminoantipyrine and dihydropyrimidone of vanillin. Int J Curr Pharm Res 2016;8:43-7.

8. Vasanth N, Melchias G, Kumaravel P. Biogenic silver nanoparticles mediated by Broussonetia papyrifera: anticancer and antimicrobial activity against pathogenic organisms. Asian J Pharm Clin Res 2017;10:93-8.

9. Deren W, Szewczyk Sadowska A, Rułka J. The eradication of enzootic bovine leucosis in a large farm population. Polish J Veterinary Sci 2003;6:12-4.

10. Borovoy V. Problems of prevention and elimination of bovine leukemia in the territory of Russia. Veterinary Farm Animals 2015;1:30-7.

11. Rułka J, Kubis P, Buzała E, Kamiński S, Deren W. The improvement of monitoring methods of cattle infection with bovine leukemia virus (BLV). Polish J Veterinary 2003;6:40-2.

12. Gutierrez G, Rodríguez SM, Brogniez A, Gillet N, Golime R, Burny A. Vaccination against $\delta$-retroviruses: the bovine leukemia virus paradigm. Viruses 2014;6:2416-27.

13. Sperka T, Miklo G, Tie Y, Bagossi P, Zahuczky G, Boross P, et al. Bovine leukemia virus protease: comparison with human $\mathrm{T}$ lymphotropic virus and human immunodeficiency virus proteases. J Gen Virol 2007;88:2052-63.

14. Gillet N, Florins A, Boxus M, Burteau C, Nigro A, Vandermeers F, et al. Mechanisms of leukemogenesis induced by bovine leukemia virus: prospects for novel anti-retroviral therapies in human. Retrovirology 2007;4:18.

15. Plotnikov E, Pehenko V, Plotnikov V. Antibacterial and immunomodulatory effects of hexamethylenetetramine (Methenamine) silver nitrate. Physiol Pharmacol 2016;19:247-52. 